\title{
FAKTOR PENDUKUNG DAN FAKTOR PENGHAMBAT KEPUASAN HIDUP PEREMPUAN EMERGING ADULTHOOD YANG MENGALAMI OBESITAS
}

\author{
Yuviena Hendra Kusuma ${ }^{1}$ \\ Eli Prasetyo ${ }^{2}$ \\ yuvienahendra8@gmail.com \\ eli@ukwms.ac.id
}

Fakultas Psikologi Universitas Katolik Widya Mandala Surabaya

\begin{abstract}
Abstrak
Kepuasan hidup merupakan salah satu tolak ukur untuk menentukan kebahagiaan seseorang. Semakin seseorang puas dengan hidupnya, maka semakin bahagia seseorang. Banyak faktor yang dapat mempengaruhi kepuasan hidup. Faktor tersebut dapat berasal dari dalam diri maupun dari luar diri. Bagi seorang perempuan yang ada pada masa transisi dari masa remaja ke dewasa yang mengalami obesitas erat kaitannya dengan kepuasan hidup. Perubahanperubahan yang dialami pada masa tersebut dengan diikuti kondisi tubuh yang obesitas tentunya menghadirkan tantangan-tantangan tersendiri bagi mereka. Perubahan-perubahan tersebut melibatkan proses kognitif. Penelitian ini menggunakan metode penelitian kualitatif dengan pendekatan fenomenologi. Informan penelitian ini adalah tiga orang perempuan dengan rentang usia 18-25 tahun yang mengalami obesitas. Pemilihan informan menggunakan metode purposive sampling dan informan penelitian diperoleh melalui snowball sampling. Selain itu, penelitian ini menggunakan teknik analisis data inductive thematic analysis. Hasil penelitian menunjukkan bahwa faktor-faktor yang mempengaruhi kepuasan hidup perempuan emerging adulthood yang mengalami obesitas dibagi menjadi 2, antara lain faktor internal dan faktor eksternal. Faktor internal yang mempengaruhi kepuasan hidup perempuan emerging adulthood yang mengalami obesitas antara lain nilai hidup, pengalaman hidup, kontrol diri, sikap menghadapi kejadian dalam hidup, religiusitas, dan kepribadian; sedangkan faktor eksternal yang mempengaruhi kepuasan hidup perempuan emerging adulthood yang mengalami obesitas antara lain hubungan dengan orang lain, dukungan sosial, pandangan orang lain, pengalaman tidak menyenangkan, serta adanya tuntutan dari keluarga.
\end{abstract}

Kata Kunci: Kepuasan Hidup, Obesitas, Perempuan Emerging Adulthood

\section{Abstract}

Life satisfaction is one of the predictor to determine one's happiness. The more a person satisfied with life, the happier they are. Many factors can affect life satisfaction. These factors can be from within or from the outside of self. For emerging adult women that in a transition period of being adult can be related to life satisfaction. The changes that occurred during that period and also the obese condition bring out challenges for them. The cognitive process also changes. This study uses qualitative method and also using phenomenology approach. The informant of this study were three women with the ages range 18-25 years old who are obese. The informants are selected by using purposive sampling method and through snowball sampling. In addition, this study used inductive thematic analysis as the data analysis technique. The result shows that the factors that affect life satisfaction of emerging adult women who are obese consist internal factors and external factors. The internal factors are value of 
life, life experiences, self-control, the attitude when facing events in life, religiosity, and personality; whereas the external factors that affect life satisfaction of emerging adult women who are obese are relationship with others, social support, unpleasant experiences, and also the indictment from family.

Keywords: Life Satisfaction, Obesity, Emerging Adulthood Women

\section{Pendahuluan}

Obesitas dapat terjadi pada semua kalangan usia dan gender. Obesitas tidak hanya terjadi di negara maju, namun juga terjadi di negara berkembang, salah satunya di Indonesia. Menurut riset yang dilakukan oleh Institute for Health Metrics and Evaluation (IHME), di negara berkembang jumlah perempuan gemuk lebih banyak dibandingkan dengan laki-laki. Kasus obesitas pada perempuan tahun 2007 hanya mencapai angka 14 persen, namun pada 2013 mencapai 32 persen. Dari data kuantitatif tersebut dapat dikatakan kasus obesitas pada perempuan mengalami kenaikan yang sangat tinggi yaitu hampir 50 persen. Simmons \& Blyth, 1987 (dalam Arnett, 2009:169) menjelaskan bahwa perempuan lebih merasa tidak puas dengan bentuk tubuhnya. Jumlah peningkatan orang yang mengalami obesitas dan dampak dari obesitas sendiri baik dari segi kesehatan maupun psikologis menunjukkan bahwa obesitas dapat dilihat sebagai suatu fenomena yang penting untuk diteliti.

World Health Organization (2017) menjelaskan bahwa obesitas merupakan keadaan abnormal atau akumulasi lemak berlebih yang berisiko terhadap kesehatan. Untuk membuktikan apakah seseorang mengalami obesitas atau tidak, bisa dengan menghitung Body Mass Index (BMI) atau indeks massa tubuh. Cara penghitungan BMI yaitu dengan cara berat badan dibagi dengan kuadrat dari tinggi badan. Klasifikasi obesitas menurut penghitungan BMInya dapat dilihat pada tabel dibawah ini:

Tabel 1. Klasifikasi Kategori BMI

\begin{tabular}{cl}
\hline BMI $\left(\mathbf{k g} / \mathbf{m}^{\mathbf{2}}\right)$ & \multicolumn{1}{c}{ Klasifikasi } \\
\hline 18.5 & Berat badan dibawah rata-rata \\
$18.5-25$ & Berat badan normal
\end{tabular}

25-30 Kelebihan berat badan

30-35 Obesitas tingkat I

35-40 Obesitas tingkat II

$>40 \quad$ Obesitas tingkat III

Sumber:http://research.omicsgroup.org/index.php/ Obesity

Tabel 1. menjelaskan klasifikasi berat badan berdasarkan penghitungan BMI. Seseorang dapat dikatakan obesitas jika memiliki BMI diatas $30 \mathrm{~kg} / \mathrm{m}^{2}$.

Masa emerging adulthood yang merupakan masa peralihan dari remaja menuju ke dewasa menunjukkan karakteristik tertentu yang membedakannya dengan periode usia lain. Karakteristik tersebut antara lain adanya eksplorasi identitas dalam hal percintaan dan pekerjaan; adanya ketidakstabilan dalam hal perubahan tempat tinggal, percintaan, pekerjaan, dan pendidikan; self-focused (terfokus pada diri sendiri) sehingga memiliki otonomi yang besar dalam mengatur kehidupannya sendiri; feeling in between (merasa seperti berada/di peralihan) sehingga tidak menganggap dirinya sebagai remaja atau sepenuhnya sudah dewasa dan berpengalaman; serta usia dengan berbagai kemungkinan karena memiliki harapan-harapan yang besar (Arnett, 2009:56). Rentang usia pada masa ini adalah 18-25 tahun.

Whitty (dalam Arnett, 2009:166) mengemukakan bahwa pemikiran seseorang yang ada pada masa emerging adulthood lebih kompleks. Perubahan cara memahami diri sendiri inilah yang juga menjadi dasar dalam perubahan fungsi kognitif. Kemampuan berpikir secara abstrak dalam mempersepsikan diri memungkinkan mereka membedakan antara diri yang sekarang dan diri yang ideal. Kemampuan tersebut memungkinkan 
munculnya beberapa dampak negatif, misalnya stres dan depresi. Keadaan stres dan depresi jauh dari kepuasan hidup. Kepuasan hidup sebagai aspek kognitif dalam menentukan subjective well-being tentunya melibatkan fungsi kognitif seseorang. Kepuasan hidup menurut Diener, Frank, Shin dan Johnson (dalam Diener dan Pavot, 1993:164) adalah proses mental individu dalam menilai kualitas kehidupan mereka atas dasar yang unik menurut kriteria mereka sendiri.

Seseorang yang mengalami obesitas pada masa emerging adulthood memiliki tantangan tersendiri. Mereka memiliki perubahan fungsi kognitif yang semakin kompleks disertai keadaan obesitas yang tentunya mempengaruhi cara mereka memandang dirinya dan mempengaruhi kepuasan hidupnya. Banyak penelitian tentang faktor-faktor yang mempengaruhi kepuasan hidup dan penelitian yang berkaitan dengan obesitas, antara lain oleh Nahdiyah (2015) mengenai Hubungan Antara Body Image Dengan Kepuasan Hidup Pada Remaja yang Mengalami Obesitas di Komunitas KAGUMI (Ikatan Wanita Gemuk Indonesia). Hasil penelitian menunjukkan bahwa ada hubungan positif antara body image dengan kepuasan hidup. Penelitian ini berfokus pada body image tanpa memperhatikan faktor lain yang dapat mempengaruhi kepuasan hidup seseorang yang obesitas. Selain itu, penelitian ini dilakukan pada komunitas wanita yang mengalami obesitas yang tentunya mempengaruhi hasil penelitian itu sendiri. Dalam penelitian didapatkan bahwa 94\% dari mereka masuk dalam tingkat kepuasan hidup yang tinggi.

Oleh karena itu, peneliti ingin meneliti faktor pendukung dan faktor yang menghambat kepuasan hidup perempuan emerging adulthood yang mengalami obesitas, sehingga tidak hanya dilihat dari satu faktor saja serta tidak hanya pada setting komunitas tetapi juga ketika ada dalam setting kehidupan sehari-hari.

\section{Metode Penelitian}

Penelitian ini menggunakan metode penelitian kualitatif. Dalam penelitian ini, peneliti ingin memahami faktor-faktor yang mempengaruhi kepuasan hidup perempuan emerging adulthood yang mengalami obesitas. Pendekatan yang digunakan adalah pendekatan fenomenologi karena pendekatan ini menurut Collin (dalam Sukidin, 2002), mampu mengungkap objek kognitif. Hal ini sesuai dengan tema penelitian ini, dimana kepuasan hidup merupakan aspek kognitif yang sifatnya sangat subjektif.

Karakteristik informan yang dipilih peneliti adalah perempuan yang berumur 18-25 tahun yang mengalami obesitas. Untuk memastikan informan mengalami obesitas/tidak, peneliti menghitung indeks massa tubuhnya dengan ukuran minimal BMI $30 \mathrm{~kg} / \mathrm{m}^{2}$. Jenis wawancara yang digunakan dalam penelitian ini adalah wawancara semi terstruktur dengan teknik analisis data yaitu inductive thematic analysis. Peneliti menggunakan metode validitas komunikatif dan validitas argumentatif.

\section{Hasil Penelitian dan Diskusi}

Berdasarkan analisa data dari ketiga informan penelitian, ditemukan bahwa terdapat faktor internal dan faktor eksternal yang mempengaruhi kepuasan hidup perempuan emerging adulthood yang mengalami obesitas. Faktor internal yang mempengaruhi kepuasan hidup:

a. Nilai hidup

Nilai hidup atau pandangan hidup sebagai suatu kesatuan nilai merupakan salah satu hasil yang dicapai orang dewasa. Krathwohl (dalam Monks, Knoers, dan Haditono, 2002:319), menyebutkan bahwa nilai hidup memungkinkan seseorang akan menempatkan semua kejadian hidupnya, dalam satu sudut pandang tertentu yang mencakup semuanya, dan pandangan inilah yang memberikan arti kepada semua hal di dalamnya. Nilai hidup yang ditemukan berdasarkan hasil analisis 
data ketiga informan terdiri dari persepsi terhadap kondisi tubuh, prinsip memahami realitas, pandangan terhadap pasangan dan pernikahan, serta prinsip terhadap pendidikan. Dalam hal ini, seseorang dengan nilai hidup yang positif tentunya akan memiliki persepsi positif terhadap tubuh, memiliki prinsip positif dalam memahami realitas dan dalam segala aspek kehidupan yang lain.

b. Pengalaman hidup

Pengalaman hidup dapat berupa pengalaman menyenangkan dan pengalaman tidak menyenangkan. Keadaan obesitas yang dialami oleh perempuan emerging adulthood, berkaitan erat dengan karakteristik emerging adulthood itu sendiri. Karakteristik yang berhubungan erat dengan pengalaman hidup, adalah adanya eksplorasi identitas. Melalui eksplorasi, akan banyak pengalaman yang didapatkan, baik itu pengalaman positif ataupun negatif. Kuppens, Diener \& Realo (2008:72) dalam jurnalnya The Role of Positive and Negative Emotions in Life Satisfaction Judgment Across Nations, menyatakan bahwa frekuensi pengalaman positif seseorang berkaitan dengan kepuasan hidupnya. Pengalaman positif dinilai dua kali lebih kuat, dalam mempengaruhi kepuasan hidup seseorang dibandingkan dengan pengalaman negatif. Hasil analisis data ketiga informan menunjukkan, bahwa pengalaman menyenangkan yang dimiliki berkaitan dengan pengalaman yang menghasilkan keuntungan bagi informan dan pengalaman berupa pencapaian terhadap suatu hal tertentu, sedangkan pengalaman tidak menyenangkan informan berkaitan dengan kesehatan dan adanya hambatan untuk melakukan suatu hal.

c. Kontrol diri
Peterson (dalam Compton, 2005:49) mengkaitkan kontrol diri dengan locus of control, yaitu keyakinan seseorang bahwa dirinya dapat bertindak dengan tujuan memaksimalkan hasil yang baik atau meminimalkan hasil yang buruk. Seseorang dengan locus of control internal yang tinggi cenderung menghubungkan hasil dengan usaha yang diarahkan oleh dirinya sendiri, bukan menghubungkannya dengan faktor eksternal. Berdasarkan hasil analisis data ketiga informan, muncul kedua locus of control dalam komposisi yang berbeda. Locus of control external lebih banyak muncul dibandingkan locus of control internal. Hal ini membuktikan bahwa masih banyak aspek-aspek dalam diri informan, misalnya seperti perilaku, kognitif, dan emosi yang dikontrol oleh lingkungan sosialnya.

d. Sikap menghadapi kejadian dalam hidup

Sikap menghadapi kejadian dalam hidup dibedakan menjadi dua, yaitu optimisme dan pesimisme. Sikap optimis merupakan sikap yang dapat meningkatkan kepuasan hidup dan kebahagiaan seseorang. Seseorang yang mengevaluasi dirinya secara positif memandang masa depan dengan penuh harapan dan ekspektasi positif. Harapan yang muncul dalam penelitian ini berupa harapan terhadap kondisi tubuh, pendidikan, perkembangan kepribadian, serta harapan setelah menyelesaikan pendidikan. Seligman, (dalam Compton, 2005:51) menyatakan bahwa seseorang dapat belajar untuk lebih optimis dengan cara memperhatikan bagaimana mereka menjelaskan peristiwa kehidupan kepada dirinya. Dalam penelitian ini muncul usaha-usaha informan untuk tetap sehat, mencapai rencana, serta usaha untuk menghargai diri sendiri. Sebaliknya, sikap pesimis 
menimbulkan keraguan dalam diri. Berdasarkan hasil analisis data ketiga informan, keraguan yang muncul berupa keraguan terhadap masa depan dan kehidupan pernikahan.

e. Religiusitas

Menurut Glock \& Stark (1969), religiusitas berfokus menjelaskan seberapa kuat komitmen seseorang terhadap substansi agama dan terdapat lima macam dimensi religiusitas, yaitu: a) dimensi keyakinan, dimensi ini berisi pengharapan dimana orang berpegang teguh pada pandangan teologis tertentu dan mengakui kebenaran doktrin tersebut; b) dimensi ritualitas (praktek agama), dimensi ini mencakup perilaku pemujaan, ketaatan, dan hal yang dilakukan orang untuk menunjukkan komitmen terhadap agama yang dianut; c) dimensi pengalaman, dimensi ini berkaitan dengan pengalaman keagamaan, perasaan, persepsi dan sensasi yang dialami seseorang; d) dimensi pengetahuan agama, dimensi ini mengacu pada harapan bahwa orang yang beragama memiliki sejumlah pengetahuan mengenai dasar keyakinan, ritus, kitab suci dan tradisi; e) dimensi konsekuensi, dimensi ini mengacu pada identifikasi akibat-akibat, praktek, pengalaman dan pengetahuan seseorang dari hari ke hari.

Berdasarkan hasil analisis data ketiga informan, ditemukan bahwa informan memiliki tingkat religiusitas yang rendah karena kurangya hubungan yang dekat dengan Tuhan. Hal ini tentu menyebabkan beberapa hal negatif terjadi pada diri informan, diantaranya perasaan tidak bahagia dan tidak puas dengan hidup. Perasaan-perasaan ini tentunya berpengaruh juga terhadap kontrol diri informan. Informan akan mengkaitkan kejadian-kejadian dalam hidup dengan faktor eksternal diluar dirinya.

f. Kepribadian

Hasil analisis data menunjukkan bahwa ketiga informan memiliki tipe kepribadian introvert. Jika dikaitkan dengan hasil analisis data, kepribadian informan yang introvert erat kaitannya dengan relasi teman sebaya. Hal ini tidak sejalan dengan penelitian yang dilakukan oleh Nursyahrurahmah (2017) tentang Hubungan antara Kepribadian Introvert dan Kelekatan Teman Sebaya dengan Kesepian Remaja yang menunjukkan bahwa terdapat hubungan positif yang signifikan antara kepribadian introvert dan kelekatan teman sebaya. Ada pula karakter-karakter negatif tertentu yang mempengaruhi kepuasan hidup informan. Hal ini dikarenakan karakter-karakter negatif tersebut menghambat diri informan khususnya dalam hal relasi dengan lingkungan sosial.

Selain faktor internal, ada pula faktor eksternal yang mempengaruhi kepuasan hidup perempuan emerging adulthood yang mengalami obesitas. Berikut uraiannya.

a. Hubungan dengan orang lain

Hubungan dengan orang lain dapat berupa hubungan positif dan negatif. Berdasarkan hasil analisis data ketiga informan didapatkan hubungan positif informan dengan keluarga dan teman. Hubungan informan ini dikaitkan dengan kedekatan informan terhadap orangtua, teman, serta bagaimana pola asuh mempengaruhi informan. Hubungan positif dengan orang lain dapat berupa keintiman secara emosional. Keintiman secara emosional dengan keluarga dan teman menurut Cummins (dalam Compton, 2005:52) adalah faktor yang paling mempengaruhi kepuasan hidup seseorang. Terdapat pula hubungan negatif informan dengan keluarga dan teman. Hubungan 
negatif informan dengan keluarga berkaitan erat dengan bagaimana keadaan keluarga informan saat ini serta sikap keluarga terhadap informan. Arnett (2009:172) mengemukakan bahwa perasaan diterima dan disetujui oleh orangtua memberikan pengaruh pada harga diri seseorang.

b. Dukungan sosial

House (dalam Yusuf dkk, 2014:266) menyebutkan bahwa dukungan sosial terbagi atas 4, yaitu dukungan instrumental, informatif, emosional, dan penilaian. Dukungan instrumental meliputi bantuan secara materi, misalnya pemberian tempat tinggal dan peminjaman uang. Selanjutnya, dukungan informatif dapat meliputi nasihat dan diskusi tentang bagaimana memecahkan masalah. Dukungan emosional dapat berupa pemberian kasih sayang, perhatian, serta kepedulian. Yang terakhir, dukungan penilaian dapat berupa penilaian dan penyadaran akan masalah yang dihadapi, mengklarifikasi masalah, serta memberikan umpan balik tentang hikmah dibalik masalah. Hasil penelitian menunjukkan bahwa semakin tinggi tingkat dukungan sosial maka semakin tinggi pula kesejahteraan subjektif. Berdasarkan hasil analisa data ketiga informan, keempat jenis dukungan sosial ini muncul dan komposisinya berbeda untuk setiap informannya.

c. Pandangan orang lain terhadap informan

Pandangan orang lain dapat mempengaruhi kepuasan hidup seseorang. Melihat bahwa pada masa emerging adulthood, mereka berfokus pada diri sendiri, lepas dari orangtua, maka akan mungkin terjadi perbedaan pendapat atau pandangan antar keduanya. Mereka memiliki otonomi yang besar dalam mengatur kehidupannya sendiri, dengan caranya sendiri. Hal inilah yang membuat mereka akhirnya tidak terlalu berfokus dan tidak seluruhnya mempertimbangkan penilaian orang lain, meskipun dalam beberapa hal, pandangan yang diterima individu tersebut terkadang dapat diterima menjadi evaluasi diri.

d. Pengalaman tidak menyenangkan

Seperti yang sudah dijelaskan pada faktor internal, pengalaman seseorang mempengaruhi kepuasan hidup. Pengalaman tidak menyenangkan yang didapatkan berupa tanggapan negatif dari orang lain serta pengalaman masa kecil. Pengalaman masa kecil yang tidak menyenangkan mempengaruhi pandangan informan terhadap hubungan pertemanan dengan orang lain sehingga hal ini tentunya berdampak pada kepuasan hidup informan.

e. Tuntutan dari keluarga

Sesuai dengan karakteristik emerging adulthood yaitu adanya self-focused, seseorang yang ada pada masa emerging adulthood cenderung memiliki otonomi yang besar dalam mengatur kehidupannya sendiri. Otonomi yang dimiliki berhubungan erat dengan bagaimana mereka mengembangkan kemandiriannya. Karena mereka tidak dapat lagi disebut remaja, maka orang-orang sekitarnya yang dalam hal ini keluarga tentunya memiliki tuntutantuntutan tertentu agar mereka dapat mengembangkan kemandiriannya tersebut. Ada pula karakteristik emerging adulthood yang erat kaitannya dengan sebuah tuntutan, yaitu karena adanya ketidakstabilan. Salah satu ketidakstabilan yang dimaksud adalah dalam hal pendidikan. Ketidakstabilan dalam hal pendidikan dapat menimbulkan tuntutan tertentu, misalnya agar segera menyelesaikan pendidikan atau dapat juga berkaitan dengan 
keputusan melanjutkan pendidikan atau bekerja.

\section{Simpulan dan Saran}

Kepuasan hidup perempuan emerging adulthood yang mengalami obesitas dipengaruhi oleh banyak faktor, baik itu dari dalam diri maupun diluar diri. Faktor internal yang mempengaruhi kepuasan hidup perempuan emerging adulthood yang mengalami obesitas dapat berupa nilai hidup, pengalaman hidup, kontrol diri, sikap menghadapi kejadian dalam hidup, religiusitas, serta kepribadian. Faktor eksternal yang mempengaruhi kepuasan hidup perempuan emerging adulthood yang mengalami obesitas terdiri dari hubungan dengan orang lain, dukungan sosial, pandangan orang lain terhadap informan, pengalaman tidak menyenangkan, serta adanya tuntutan dari keluarga.

Diharapkan informan dapat memaknai hidupnya secara lebih positif karena melihat bahwa dari penelitian ini beberapa informan masih belum dapat memaknai hidup secara lebih positif, dan hal tersebut mempengaruhi kepuasan hidupnya dalam beberapa hal. Selain itu, bagi keluarga informan, khususnya orangtua diharapkan terus memberikan dukungan kepada informan, khususnya dukungan secara emosional. Dukungan emosional yang misalnya berupa penerimaan sangat mempengaruhi kepuasan hidup informan.

\section{Daftar Pustaka}

Arnett, J. J. (2009). Adolescense and emerging adulthood: Third edition. New Jersey: Pearson Education, Inc.

Compton, C. (2005). An introduction to positive psychology. Canada: Wadsworth.

Diener, E. \& Fujita, F. (2005). Life satisfaction set point: Stability and change. Journal of Personality and Social Psychology, 88, 158-164.

Diener, E. \& Pavot, W. (1993). Review of The Satisfaction With Life Scale.
Psychological Assessment, 5, 164172.

Glock \& Stark. (1969). Religion and society in tension. California: Rand Mc Nally Company.

Jumlah Orang Obesitas di Indonesia Terus Meningkat, Indonesia Masuk 10 Besar Negara dengan Orang Gemuk Terbanyak Menurut Riset. National Geographic. Diakses tanggal 23 Februari 2017 pada laman http://nationalgeographic.co.id/berita/ 2014/06/jumlah-orang-obesitas-diindonesia-terus-meningkat.

Kuppens, P., Diener, E., Realo, A. (2008). The Role of Positive and Negative Emotions in Life Satisfaction Judgment Across Nations. Journal of Personality and Social Psychology, 95, 66-75.

Memprihatinkan, Kasus Obesitas di Indonesia Terus Naik. Tempo. Diakses tanggal 23 Februari 2017 pada laman https://cantik.tempo.co/read/news/20 $\underline{16 / 11 / 18 / 332821350 /}$ memprihatinkan-kasus-obesitas-diindonesia-terus-naik.

Nahdiyah, I. (2015). Hubungan antara body image dengan kepuasan hidup pada remaja yang mengalami obesitas di komunitas KAGUMI (Ikatan Wanita Gemuk Indonesia). Skripsi (tidak diterbitkan).

Nursyahrurahmah. (2017). Hubungan antara Kepribadian Introvert dan Kelekatan Teman Sebaya dengan Kesepian Remaja. Jurnal Ecopsy, 4 (2).

Sukidin \& Basrowi. (2002). Metode penelitian kualitatif: Perspektif mikro. Surabaya: Insan Cendekia.

World Health Organization. (2017). Obesity. Diakses pada tanggal 20 Februari 2017 dari http://www.who.int/topics/obesity/en/ Yusuf, L.N., Syamsu., Nurihsan., Juntika, A. (2014). Landasan Bimbingan dan Konseling. Bandung: PT Remaja Rosdakarya. 